\title{
Gatunek information scraps w indywidualnym/ grupowym zarządzaniu informacją
}

\author{
Paulina Krzanowska \\ CommsBlack Sp. z o.o. \\ Marek Nahotko \\ Instytut Informacji Naukowej i Bibliotekoznawstwa, Uniwersytet Jagielloński
}

\begin{abstract}
Abstrakt
Cel/Teza: Celem artykułu jest prezentacja roli gatunków informacji w indywidualnym (niezinstytucjonalizowanym) zarządzaniu informacją na przykładzie systemu gatunków zwanych notatkami lub information scraps tworzonymi w sposób tradycyjny (bez stosowania narzędzi elektronicznych). Koncepcja/Metody badań: W badaniach grupy studentów zastosowano dwie komplementarne metody badań jakościowych: swobodny wywiad ukierunkowany oraz analizę zebranego materiału empirycznego (odręcznych notatek). Wywiad pozwolił na zebranie wypowiedzi respondentów nt. celów stosowania notatek. Zebrane notatki były analizowane z punktu widzenia formy i treści. Metodologia ta pozwoliła na dokonanie analizy gatunkowej information scraps, która zgodnie z literaturą przedmiotu dotyczyć powinna trzech cech gatunku: celu, treści i formy, w tym formy językowej.

Wyniki i wnioski: Information scraps stanowią system gatunków wspomagających zarządzanie informacją. Ich forma i treść dostosowane są do realizowanych celów komunikacyjnych: kognitywnych, afektywnych, estetycznych i edukacyjnych. Stosowane są w sytuacjach standaryzowanych i powtarzalnych działań komunikacyjnych.

Oryginalność/Wartość poznawcza: Stosowanie notatek w działaniach indywidualnych wspomaga tworzenie wspólnego gruntu stanowiącego podstawę działań grupowych, stąd information scraps, jak każdy gatunek, wspomagają społeczne działania komunikacyjne.
\end{abstract}

\section{Słowa kluczowe}

Analiza gatunkowa. Gatunki informacji. Indywidualne/Grupowe zarządzanie informacją. Notatki odręczne

Otrzymany: 12 grudnia 2018. Z Zrecenzowany: 27 grudnia 2018. Zaakceptowany: 22 stycznia 2019.

\section{Wstęp}

Człowiek, podobnie jak każdy organizm żywy, może być traktowany jako system informacyjny, internalizujący informację, przetwarzający ją i eksternalizujący ${ }^{1}$. Z drugiej strony, wszelkie działania ludzkie są społeczne w szerokim tego słowa znaczeniu, a więc związane są z komunikowaniem się z innymi ${ }^{2}$. Każdy z nas zarządza informacją przekazywaną przez

1 W procesach tych tworzona i modyfikowana jest indywidualna wiedza.

${ }^{2}$ Niektóre działania, takie jak: śpiewanie (na scenie), słuchanie muzyki, czytanie, oglądanie filmów i dzieł plastycznych w sposób oczywisty służą komunikacji, rozumianej jako przekazywanie informacji. Inne, jak pisanie pamiętnika lub notatek tylko pozornie nie służy komunikowaniu się z innymi, co przedstawione zostanie w dalszej części artykułu. 
innych ludzi oraz danymi spoza środowiska społecznego ${ }^{3}$. Oznacza to, że każde działanie związane jest w jakimś stopniu z zachowaniami informacyjnymi, rozumianymi jako aktywności, działania i reakcje ludzi pojawiające się w momencie zetknięcia się ze źródłami lub kanałami informacyjnymi, takie jak aktywne i pasywne poszukiwanie informacji i jej wykorzystanie (Wilson, 2000, 49). Zachowania te służą realizacji potrzeb informacyjnych, których posiadanie jest immanentną cechą każdego człowieka. Podczas zarządzania informacją i jej organizacji w specyficzny sposób łączone jest to, co jednostkowe (indywidualne zarządzanie informacją, ang. Personal Information Management - PIM) z tym, co społeczne (grupowe zarządzanie informacją, ang. Group Information Management GIM). W procesach tych wykorzystywane są narzędzia dwojakiego rodzaju - mentalne (wewnętrzne) i techniczne (zewnętrzne), łącznie charakteryzujące stosowany gatunek informacji. Pierwsze służą do ujednolicania znaczeń (tworzenia konwencji społecznych) umożliwiającego komunikację; drugie wykorzystywane są do przekazywania, utrwalania i organizacji komunikowanej informacji. W artykule zostaną przedstawione wyniki badań dotyczących obu aspektów zarządzania informacją na przykładzie specyficznego gatunku informacji, jakim są odręcznie tworzone notatki (ang. information scraps). Celem badań jest ujawnienie za pomocą analizy gatunkowej notatek zastosowania tego specyficznego gatunku informacji w procesach organizacji informacji.

\section{Indywidualne i grupowe zarządzanie informacją}

Zainteresowanie PIM i GIM wynika z zauważenia skądinąd oczywistego faktu, że jednostka (osoba) nie staje się użytkownikiem informacji jedynie z chwilą przekroczenia progu biblioteki lub stosowania innego, zinstytucjonalizowanego systemu informacyjnego. Człowiek jest biologiczną maszyną informacyjną, która nieprzerwanie przetwarza zarówno materię, jak i informację, pozwalającą na dostęp do materii i właściwy z niej użytek. Przetwarzanie informacji odbywa się nieustannie, w sposób świadomy i nieuświadomiony (np. także we śnie). W takim razie odbywa się we wszystkich kontekstach, spośród których w informatologii zwykle wyróżnia się kontekst zawodowy i pozazawodowy (osobisty). W normalnej sytuacji oba zawsze się mocno splatają.

Wielość kontekstów wynika z faktu, że potrzeby informacyjne i zachowania, których potrzeby są przyczyną, to zjawiska społeczne, realizowane w społecznym otoczeniu, bliższym i dalszym. Dlatego podział na PIM i GIM jest umowny, zarządzanie informacją może być mniej lub bardziej indywidualne lub grupowe. Jest to więc pewne kontinuum, od mocno indywidualnego do bardzo grupowego zarządzania informacją, ale nigdy nie jest zupełnie pozbawione kontekstu społecznego. Jednocześnie zawsze jest w pewnym stopniu indywidualne. Remigiusz Sapa podkreślał dwoistość PIM/GIM odpowiadającą temu kontinuum, wskazywał na funkcjonowanie tych procesów w obu kontekstach: indywidualnym

\footnotetext{
${ }^{3}$ Terminy „dane”, „informacja” $\mathrm{i}$ „wiedza” rozumiane są tak, jak to zostało przedstawione w (Nahotko, 2018, 69 i nast.).

${ }^{4}$ Narzędzia mentalne rozumiane są jako struktury mentalne służące do bezpośredniego i celowego oddziaływania na czynności realizowane przez jednostkę, sterując ich wykonywaniem. Mogą one być traktowane jako narzędzia przez analogię do oprogramowania komputerowego. Część narzędzi mentalnych stosowana jest w procesach komunikacyjnych.
} 
i grupowym. W pierwszym przypadku PIM/GIM może być przejawem działalności indywidualnej nakierowanej na potrzeby całej grupy. Kontekst grupowy oznacza postrzeganie grupy jako całości i skupianie się przede wszystkim na zarządzaniu informacją przez tak rozumianą grupę (Sapa, 2017, 369-380). Stąd w dalszej części artykułu będziemy posługiwali się skrótem PIM/GIM oznaczającym to kontinuum.

Krótkie wprowadzenie do problemów PIM/GIM zaczniemy od indywidualnego końca kontinuum. William Jones w 2007 r. podał trzy aspekty zarządzania indywidualnego, które w 2016 r. zostały przez niego uzupełnione o kolejne trzy. Pierwszy wskazuje na to, że zarządzanie dotyczy informacji należącej do jednostki zarządzającej, przez nią kontrolowanej i wykorzystywanej do celów osobistych. Drugi odnosi się do posiadanej przez innych informacji o jednostce. Kolejny wskazuje na jednostkę jako odbiorcę informacji, bez względu na to, czy odczuwa ona potrzebę tej informacji (może to być np. informacja dostarczana przez reklamy). Wyróżnił także informację, którą jednostka komunikuje innym, np. wysyłając pocztę elektroniczną. Indywidualne autorstwo sprawia, że takie działanie traktowane jest również jako zarządzane indywidualnie. Jones pisał też o informacji pozyskiwanej poprzez doświadczenia jednostki oraz informację ogólnie nazwaną relewantną względem działań (również przyszłych) i zainteresowań jednostki (Jones, 2007, 461-462; Jones et. al., 2016, 573). Podobne stanowisko w tej sprawie przyjmował wcześniej Mark Lansdale, nie traktując informacji własnej (Tomaszczyk, 2017, 210) jako czegoś prywatnego, dostępnego wyłącznie dla jednostki ${ }^{5}$. Indywidualność oznacza możliwość samodzielnego używania, uzyskiwania (ang. retrieve) oraz wielokrotnego wykorzystania tego rodzaju informacji (Lansdale, 1988, 55).

Jones odnosił PIM/GIM do teorii i praktyki wszelkich działań względem informacji wykorzystywanej w kontekstach zawodowym i osobistym oraz w wypełnianiu obowiązków wynikających z pełnionej roli społecznej (np. bycia członkiem rodziny lub innej społeczności). Wymienia on aż osiem rodzajów działań PIM/GIM, do których zaliczyć można m.in.: nabycie (ang. acquire) lub stworzenie, organizowanie, użytkowanie i rozpowszechnianie (ang. distribute) informacji. Wszystkie wymienione działania służą umieszczeniu właściwej informacji we właściwym miejscu i formie, w celu realizacji potrzeb informacyjnych. Czasami Jones zwięźle określa PIM/GIM jako sztukę stosowania informacji dla realizacji czynności życiowych (Jones, 2007, 453; 2015, 5). Analogiczne określenie indywidualnego zarządzania informacją znaleźć można w publikacjach Briana Detlora oraz Katarzyny Materskiej. Pierwszy autor opisywał działania informacyjne podejmowane dla osiągnięcia indywidualnych celów jednostki. Wyróżnia on sześć kroków: nabycie lub stworzenie, uporządkowanie, przechowywanie, wykorzystywania na własny użytek, rozpowszechnianie (Detlor, 2010, 107). K. Materska krytycznie odnosi się do tego rodzaju definicji wyliczających. Jej zdaniem należałoby skupić większą uwagę na procesach realizowanych w osobistej przestrzeni informacyjnej jednostki, bowiem jest to miejsce wielu interakcji w kontekście PIM (Materska, 2012, 67). Przestrzeń ta (ang. personal space of information, PSI) obejmuje wszystkie elementy (ang. information items) będące w posiadaniu jednostki, mające wartość informacyjną, a także wszelkie narzędzia (np. aplikacje) wspomagające procesy zarządzania nimi. Według Mirosława Górnego PSI składa się także z elementów mentalnych, takich

5 Traktowanie informacji jako indywidualnej własności byłoby sprzeczne z jej definicją przyjętą w artykule, traktującą informację jako reprezentację wiedzy przekazywanej w procesie komunikacji. 
jak: wiedza, doświadczenie, umiejętności, postawy, wierzenia, uprzedzenia związane z realizacją zadań informacyjnych (Górny et. al., 2017). Każda jednostka posiada tylko jedną PSI. Elementy materialne w niej zawarte mogą występować w formie tradycyjnej i/lub elektronicznej. Są bezpośrednio i szybko dostępne do wykorzystania w procesach kognitywnych. Przestrzeń ta podzielona jest na mniejsze „wyspy”, zwane osobistymi kolekcjami informacji (ang. personal information collections - PIC), podzbiorami wypełnionymi zorganizowanymi w ten sposób elementami informacyjnymi. PIC mogą różnić się liczbą, formą i spójnością treści organizowanych elementów. Organizacja elementów obejmuje ich układ przestrzenny, strukturę, właściwości i atrybuty. Stosowane są w różnych celach, są to np. w różnym stopniu uporządkowane dokumenty firmowe znajdujące się w biurkach i szafkach oraz w folderach komputerów, zbiory elementów informacji specyficznych dla danego projektu, które są pierwotnie umieszczone w folderze, a następnie sukcesywnie opracowywane (Jones, 2007, 460, 462-463; 2015, 129-130). PSI budowaną w procesach PIM można uważać za część publicznej przestrzeni informacyjnej, w której realizowane są procesy GIM.

William Jones podkreśla, że PIM/GIM ma istotny wymiar praktyczny. W kontekście jednostki ma ono znaczny wpływ na gospodarowanie takimi dobrami, jak: czas, finanse oraz własna energia, natomiast w przypadku organizacji zasadnicze znaczenie ma wpływ na wydajność pracowników oraz ich relacje zawodowe w grupie (Jones, 2007, 456-457). Problemem występującym w całym kontinuum PIM/GIM jest tzw. fragmentaryzacja (rozproszenie) informacji, polegająca na stosowaniu wielu formatów i narzędzi do jej materializacji. Informacja zapisana w wersji tradycyjnej może być łatwo skonwertowana na wersję elektroniczną i odwrotnie. Korzystanie z kilku kont poczty elektronicznej, zapisywanie informacji na dyskach komputerów lub pamięciach przenośnych, w osobistych organizerach, a nawet w telefonach komórkowych, to tylko kilka przykładów wskazujących na problemy fragmentaryzacji informacji i jej wpływu na efektywne zarządzanie informacją (Jones, 2007, 453; Materska, 2012, 71).

Na drugim końcu kontinuum PIM/GIM znajduje się grupowe zarządzanie informacją. W zależności od sposobu traktowania „grupy” wyznacza się trzy możliwe perspektywy. Pierwsza z nich odnosi się do możliwości wywierania wpływu przez grupę na PIM/GIM każdej jednostki wchodzącej w zasięg jej oddziaływania. Kolejna perspektywa odnosi się do sposobów dzielenia się informacją pomiędzy jednostkami w grupie oraz zarządzania wspólnymi zasobami informacyjnymi (Teevan et al., 2008, 104). Są to dwa konteksty tego samego zjawiska. W. Jones, definiując GIM wskazał, że jest to suma działalności pojedynczych jednostek, a ich praktyki stosowane w zarządzaniu informacją mają największy wpływ na funkcjonowanie grupy jako całości (Jones, 2015, 3). Podobne zdanie wyrażali W. Lutters, M. Ackerman i X. Zhou, wskazując, że GIM funkcjonuje także w kontekstach zawodowym i prywatnym, w tym domowym (Lutters et al., 2007, 236-237 i 243). Z kolei T. Erickson traktuje GIM jako PIM, działający w znacznie szerszym, społecznym zakresie. Przedstawił on nawet prosty model GIM zawierający się w jednym zdaniu:

Jednostka generuje informację, którą dzieli się z grupą w celu wspierania wspólnych działań (Erickson, 2006, 74-75)

\footnotetext{
${ }^{6}$ Wszystkie cytaty z prac nieopublikowanych dotychczas w języku polskim są tłumaczeniami autorów niniejszego artykułu [red.].
} 
Za pomocą tego modelu cytowany autor prezentował problemy i zagadnienia PIM/GIM, odnoszące się do trzech kwestii: dotyczących informacji bezpośrednio, np. jej organizacji i struktury; dotyczących czynności dzielenia się informacją, np. przepływów informacji i sposobów ich organizacji; oraz związanych ze wspieraniem i wykonywaniem działań, np. problemy zapewnienia prywatności i kontroli własnych zasobów informacyjnych.

\section{Gatunki informacji jako mentalne narzędzia PIM/GIM}

Gatunek informacji rozumiany jest jako typizowana forma komunikacji realizowanej we wszystkich kontekstach aktywności ludzkiej, głównie osobistym i zawodowym, a także we wszystkich praktykach społecznych (Devitt, 2004; Luckmann, 2009). Taka typizacja ma miejsce podczas każdego aktu komunikacji społecznej (wymiany informacji). Nie istnieją wypowiedzi „pozagatunkowe”. Oznacza to, że gatunek jest bardzo wydajnym narzędziem badania i zrozumienia stosowanych form komunikacji dzięki wspomaganiu przez niego wyjaśniania celów i sposobów stosowania różnych form informacji i jej materializacji w działalności ludzkiej, a także badania struktur społecznych tworzących gatunki i ich roli w koordynacji różnych form organizacji społecznej, w tym organizacji informacji. Gatunek jest więc rodzajem klamry łączącej społeczne, powszechne stosowanie informacji z kontekstem indywidualnego, lokalnego dostosowania i interpretacji. Dla właściwej koordynacji działań społecznych zasadnicze znaczenie ma oddziaływanie ${ }^{7}$ gatunku (ang. uptake) w konkretnej sytuacji komunikacyjnej (Freadman, 2002). Ponieważ oddziaływanie gatunku ma zarówno wymiar indywidualny (wiedza jednostkowa), jak i zbiorowy (wspólny grunt), gatunki zawsze służą mediacji pomiędzy komunikacją na poziomach indywidualnym i społecznym. Gatunek jest więc zawsze obciążony sprzecznościami spowodowanymi jednoczesnym funkcjonowaniem w indywidualnym i społecznym kontekście komunikacyjnym. Jest więc narzędziem komunikowania służącym jednostkom do wykonywania rozpoznawalnych działań komunikacyjnych realizowanych w obrębie tych kontekstów lub pomiędzy nimi (Andersen, 2017, 5).

W ten sposób rozumiane gatunki nazywane były dotąd w literaturze różnymi terminami. Pisano więc o gatunkach tekstu (np. Isenberg, 1978; Miller, 1984; Franke, 1987), mowy (Bachtin, 1986), dokumentu (Kwaśnik \& Crowston, 2005), wypowiedzi (Gajda, 2009) oraz komunikacji (Luckmann, 1986; Swales, 1990). W tym artykule używany będzie termin gatunki informacji. Aktywność komunikacyjna, typowa dla ludzi i tworząca standaryzowaną przestrzeń informacyjną, jest jedną z głównych funkcji życiowych. Komunikacja służy przekazywaniu informacji, natomiast tekst jest stosowany w tym procesie jako najbardziej efektywny, ale nie jedyny sposób materializacji informacji. Jeżeli za Carolyn Miller (1984, 162) przyjmiemy, że cel komunikacyjny jest najważniejszą cechą charakteryzującą gatunek, to musimy zauważyć, że cel ten jest osiągany za pomocą przekazywania informacji. Forma jej materializacji - tekstowa (piśmienna lub werbalna) albo inna, na przykład gestykularna,

7 Oddziaływanie definiowane jest jako nieprzewidywalne, improwizowane, wielokierunkowe funkcjonowanie gatunku w rzeczywistym czasie i miejscu. Uptake pozwala zrozumieć sposób, w jaki systematyczne, typowe relacje między gatunkami koordynują złożone formy działań społecznych - jak i dlaczego gatunki oddziałują w określony sposób oraz co jest wykonywane lub niewykonywane, jako wynik ich oddziaływania. 
jest ważna, ale nie pierwszorzędna. Cel komunikacyjny jest osiągany przez przekazywanie informacji z wykorzystaniem form i treści typowych dla gatunku. Gatunek funkcjonuje pomiędzy informacją a jej materializacją, dla której dobierane są narzędzia techniczne zapewniające osiągnięcie celu komunikacyjnego z uwzględnieniem projektowanego odbiorcy informacji. Informacja jest sednem każdego tekstu, bez niej tekst traci sens.

Każda nowa informacja jednocześnie wzmacnia i przemodelowuje pewne aspekty gatunku, każdy odbiór informacji przekształca jej społeczne rozumienie. Użytkownik musi włączyć w swoje struktury mentalne wiedzę o możliwych działaniach informacyjnych związanych ze stosowaniem gatunku. Można więc mówić o gatunku jako mentalnym wzorcu (schemacie) umieszczonym w kompetencji językowej nadawcy i odbiorcy, wynikającym z posiadanej wiedzy (zinternalizowany model językowy) (Gajda, 2009, 138). Wzorce stanowią element wiedzy użytkownika języka i są używane do wyzwalania procesów kognitywnych w celu wykonywania zadań komunikacyjnych (Maciejewski, 2009, 85). Jak wspomniano wcześniej, gatunek stanowi informacyjne ujęcie typowej sytuacji/wydarzenia związanego z działaniem w otaczającej rzeczywistości. Mentalną reprezentacją wydarzenia/ działania jest schemat poznawczy, model fragmentu rzeczywistości. Część wydarzenia/ działania stanowią obiekty informacyjne wspomagające wymianę informacji pomiędzy uczestnikami. Gatunek należy postrzegać jako rodzaj schematu mentalnego, dobieranego odpowiednio do innych schematów wydarzeń/działań związanych z sytuacją. Schemat ten pozwala na konstruowanie relacji pomiędzy elementami sytuacji komunikacyjnej i innymi elementami, związanymi z innymi sytuacjami, których częścią jest proces komunikacji.

Analiza gatunków opiera się na dwóch głównych założeniach: podobieństwo komunikatów (np. tekstów) zależy od cech związanych ze społecznym kontekstem ich tworzenia i stosowania, a cechy te mogą być opisane w sposób, który wskazuje na relacje badanego tekstu z innymi, podobnymi tekstami oraz z wyborami i ograniczeniami wpływającymi na twórców tekstu (Hyland \& Salager-Meyer 2008, 303). Traktowanie gatunku jako działania społecznego powoduje zwracanie uwagi w trakcie analizy na cel komunikacyjny komunikatu jako główną cechę gatunku (Askehave \& Swales 2001, 197). Język i jego narzędzia postrzegane są jako należące do rzeczywistości społecznej, a jednocześnie budujące ją, co odbywa się poprzez powtarzalne stosowanie skonwencjonalizowanych form komunikacyjnych, przy pomocy których jednostki tworzą relacje, budują społeczności i realizują swoje zadania. Z tego punktu widzenia gatunki są efektem grupowej aktywności pojedynczych agentów społecznych, działających zarówno w granicach swojej historii, jak i w ograniczeniach narzucanych przez kontekst oraz posiadających wiedzę o istniejących gatunkach. Są więc elementem procesów PIM/GIM.

JoAnne Yates i Wanda Orlikowski $(1992,301)$ sugerują, że dla celów analizy gatunki mogą być charakteryzowane przez podobieństwo tekstów w zakresie treści (sensu) i formy. Treść dotyczy społecznych motywacji, problemów i tematów wyrażanych podczas komunikacji, a forma określana jest przez widoczne cechy fizyczne i językowe komunikacji, takie, jak struktura, nośnik, język lub system symboliczny. Inni cechy te nazywają celem (zamiarem) i formą (Crowston \& Williams 2000, 202; Yates et al., 1997). Podobnie jak poprzednio cel dotyczy intencji komunikacyjnych, a forma cech głównie językowych. Shepherd i Watters dla gatunków tekstów elektronicznych dodają trzecią cechę (oprócz treści i formy), mianowicie funkcjonalność, ze względu na to, że nośnik elektroniczny posiada specyficzne cechy funkcjonalne. Cechy te odnoszą się do nowych możliwości, jakie 
oferują media elektroniczne (Shepherd \& Watters 1999, 2007). Jan Ljungberg (2008) na tej podstawie zaproponował zestaw cech: treść (rodzaj informacji), forma (format prezentacji treści), funkcjonalność (możliwości związane z nośnikiem) i cel (potrzeby indywidualne realizowane społecznym otoczeniu).

\section{Information scraps jako gatunek informacji}

Pomimo tego, że obecnie dostępna jest spora liczba narzędzi elektronicznych stosowanych w PIM/GIM, nadal tworzona jest informacja, której materializacja pozostaje poza zasięgiem tych narzędzi. Gromadzona jest w postaci notatek na karteczkach typu Post-it, zapisków na skrawkach papieru wkładanych pospiesznie do kieszeni lub umieszczanych w widocznym miejscu (pulpit biurka, drzwi lodówki) albo przechowywanych w specjalnych zeszytach, pojemnikach lub inaczej zorganizowanych zbiorach. Jej treść jest różnorodna, od pojedynczych wyrazów i szkiców po wielozdaniowe notatki, listy wieloelementowe, a nawet wiersze. Są obecne we wszystkich sytuacjach życiowych, stale noszone albo zapełniające sprzęty w miejscu pracy, często naklejane na monitory komputerów (Bernstein et. al., 2008, 2).

W literaturze obcojęzycznej znaleźć można kilka terminów określających ten gatunek informacji. Stosuje się następujące nazwy: micronotes, notes-to self, post-it-notes, sticky notes, move-it sticky notes oraz information scraps. Każda z nich odnosi się do tego samego zjawiska, stąd używane są zamiennie. Świadczą o tym definicje słownikowe. Post-it według Cambridge Dictionary oznacza mały kolorowy skrawek papieru przeznaczony do notowania krótkich wiadomości, który może być prowizorycznie przymocowany do pewnej powierzchni (Post-it note, 2017). Istotna jest tu wzmianka o formie notatki, zwrócenie uwagi na to, iż może to być dowolny skrawek kartki lub papieru, niekoniecznie przeznaczona do tego karteczka. W English Oxford Living Dictionary ta sama definicja umieszczona jest pod dwoma hasłami: sticky oraz post-it (Sticky, 2017). Micronotes, zdaniem Min Lin, Wayne Luttersa oraz Tiny Kim $(2004,687)$, to krótkie, wyrażane zwykle w kilku słowach, osobiste notatki kierowane do samego siebie, rejestrujące informacje godne uwagi (ang. notable information). Ich treść zapisywana jest nie tylko na karteczkach typu Post-it, ale także innych łatwo dostępnych nośnikach, czasami również na dłoniach. Celem ich tworzenia jest zapisywanie informacji aktualnych i bieżących, które będą użyteczne w przyszłości.

W polskiej literaturze przedmiotu brakuje publikacji na ten temat, stąd nie ma adekwatnego terminu, który w pełni odpowiadałby terminom angielskim. Przybliżone znaczenie ma termin notatka, której definicja w Słowniku Języka Polskiego składa się z kilku części: jest to „krótki tekst, uwaga, spostrzeżenie zapisane w celu zapamiętania, zapisek” lub „krótka informacja, wzmianka w prasie; notka” oraz „kartka z notatką, zapiskiem” (Notatka, 1979, 395). W definicji wskazuje się na kilka gatunków, wymieniając notatkę, zapisek, notkę. Jednak nie jest ona wystarczająco rozbudowana, brakuje w niej kilku kluczowych aspektów. Stąd w dalszej części artykułu jako główne określenie przyjęto termin information scraps, stosowany przez Michaela Bernsteina et. al. (2008, 2-3), używany zamiennie z polskim terminem notatka.

Bernstein et. al. (2008) wskazują na trzy cechy information scraps jako gatunku: występowanie na skrawkach, świstkach, fragmentach, wycinkach papieru (forma), niekompletność treści oraz stosowanie niestandardowych narzędzi podczas PIM/GIM. Autorzy mają 
na myśli np. zanotowane informacje adresowe nienadające się do utrwalenia w książce adresowej lub listę rzeczy do zrobienia utworzoną bez użycia aplikacji do zarządzania listami zadań. W literaturze często podkreśla się także nieformalny, nieoficjalny charakter notatek, co jest zaletą zwiększającą częstotliwość stosowania. Są regularnie stosowane ze względu na łatwość obsługi, elastyczną formę, dopasowanie formy do treści i możliwość przechowywania w dowolnym PIC (van Kleek, 2011, 2907). W ocenie M. Bernsteina i in. information scraps posiadają również inne cechy gatunkowe, przedstawione poniżej:

- szybka i łatwa percepcja treści w nich zawartych (ang. lightweight capture);

- możliwość zapisu treści w wybranej formie (ang. flexible contents and representation);

- wszechstronne zastosowania, tworzenie własnych systemów organizacji informacji lub adaptacja do narzędzi już wykorzystywanych (ang. flexible use and organization);

- $\quad$ wspomaganie pamięci dzięki widoczności/czytelności/dostrzegalności (ang. visibility and reminding);

- mobilność wspierająca dostępność (ang. mobility and availability) (Bernstein et. al., 2008, 5).

Informacja w gatunku information scraps przyjmuje wiele form. Wynika to z cechy gatunkowej notatek, jaką jest łatwe dostosowanie do indywidualnych potrzeb i preferencji. Interesujące spostrzeżenie przedstawili Max van Kleek i in. (2011, 2911), którzy wskazali na dwie postaci information scraps związane z celami komunikacyjnymi. Po pierwsze, są to notatki, które służą do zapisu informacji o czymś, co notujący zrobił lub doświadczył, w celu kontrolowania tej sprawy na bieżąco lub śledzenia jej dalszego rozwoju, w trakcie którego stosowane są kolejne gatunki. Zostało to określone jako prowadzenie dziennika (ang. journaling) lub kroniki (ang. chronicling). Po drugie, celem notatek jest zachowanie informacji ze względu na jej wartość osobistą lub emocjonalny, sentymentalny charakter. Wyróżniono cztery najbardziej typowe formy information scraps. Są to: listy zadań, spraw do załatwienia (ang. to-dos), notatki tworzone w trakcie spotkań (ang. meeting notes), informacje kontaktowe (ang. name and contact information) oraz notatki instruktaże (ang. how-to guides). Formy te zostały ustalone na podstawie badań Bernsteina i in., którzy dodatkowo dokonali podziału information scraps pod względem nakładu pracy, wysiłku włożonego w organizację notatek. Podzielono je na trzy kategorie: wymagające małego, średniego i dużego wysiłku. Małego trudu wymagają notatki fragmentaryczne, posiadające szczególne znaczenie dla notującego albo odseparowane od innych informacji. Przybierają one formę pojedynczych elementów. Mają być stale dostępne i widoczne, stąd nie ma potrzeby stosowania dla nich specjalnych narzędzi tworzenia i archiwizacji. Wysiłek włożony w ich organizację jest niski, ponieważ ogranicza się tylko do umieszczenia ich w widocznym miejscu. Organizacja notatek zawierających informację powtarzalną w różnych wariantach aktywuje umiarkowany poziom wysiłku. Użytkownik takiej notatki musi włożyć więcej trudu w gromadzenie treści jednej kategorii w jednym miejscu. Jego praca polega na grupowaniu notatek w jednolite, wewnętrznie nieuporządkowane zbiory. Dopiero połączenie archiwizacji i organizacji informacji oznacza najwyższy poziom wysiłku (Bernstein et. al., 2008, 19 i 37-38).

Information scraps, jak wszystko na tym świecie, mają swój początek i koniec. M. Lin, W. Lutters i T. Kim opracowali ośmioetapowy „cykl życia” notatek. Rozpoczyna się on wraz z odczuwaniem chęci lub konieczności zapisania informacji. Następny etap obejmuje zarejestrowanie treści notatki. W tym miejscu przewidziano dwie możliwości dalszego 
ich „życia”. Może nastąpić transfer treści do innego narzędzia, w tym elektronicznego lub mogą one być zachowane w aktualnej formie w celu dalszego ich wykorzystania. W drugim przypadku muszą być dokładne, przechowywane w widocznym miejscu i uaktualniane, ponieważ ponowne ich wykorzystanie zależy od tego, czy są natychmiast dostrzegalne, czytelne i zrozumiałe. Etap zatrzymania ich dla siebie wiąże się ze stałym odnoszeniem się, nawiązywaniem, sprawdzaniem. Oznacza to posiadanie wiedzy o ich istnieniu oraz powracanie do nich i przypominanie sobie ich treści. Kolejny etap określany jest przez cytowanych autorów jako complete; dzięki odpowiednim działaniom w poprzednich etapach notatka spełniła zamierzony dla niej cel. W tym momencie staje się bezużyteczna i można postąpić z nią na dwa sposoby: albo ją zarchiwizować, albo się jej pozbyć. W pewnych sytuacjach są zachowywane przez dłuższy okres, od kilku dni po lata. Niektórzy przechowują je tak długo, jak tylko to możliwe i decydują się na ich pozbycie dopiero w przypadku braku miejsca (Lin et al., 2004, 689-692).

W szeroko pojętym zarządzaniu informacją information scraps służą realizacji celów komunikacyjnych. Jest ich tak wiele, jak działań, którym mogą towarzyszyć. Wykorzystywane są w trakcie planowania i realizowania aktywności do zapisu informacji ważnych z punktu widzenia osoby notującej. Mogą być tworzone na podstawie kilku źródeł jednocześnie, stając się swego rodzaju zewnętrzną pamięcią, przydatną wszystkim podstawowym operacjom myślowym (Piolat et al., 2005, 291). W literaturze najczęściej opisywane są jako tymczasowe miejsce przechowywania informacji oraz ewentualne zabezpieczenie przed zapomnieniem. Poza tym odgrywają rolę kognitywnego wsparcia (ang. cognitive support), czyli stają się miejscem, w którym umieszczane są informacje dotyczące wszelkich pomysłów, obserwacji, wniosków i innych efektów „trudnych procesów myślowych”. Czasami są swego rodzaju archiwum, jeśli notujący stwierdzi, iż zapisana informacja musi być przechowana na dłużej (Bernstein et. al., 2008, 4-5 i 35-36).

Tworzenie notatek jest czynnością złożoną, która obejmuje zdolności poznawcze oraz procesy twórcze. Takie ich rozumienie skłania do stwierdzenia, iż do ich tworzenia niezbędne są kognitywne kompetencje notującego, rozumiane jako zdolność do aktywności umysłowej o charakterze poznawczym. Dotyczą one percepcji, rozumienia, uczenia się i działania, które nieodłącznie powiązane są ze zbieraniem informacji, formułowaniem hipotez, wyciąganiem wniosków i rozwiązywaniem zadań (Kubiński, 2005, 131; Piolat et al., 2005, 292 i 305). Uzasadnia to silną pozycję notatek w sferze kognitywnej i potwierdza konieczność posiadania umiejętności poznawczych niezbędnych do realizacji procesu notowania. Można przyjąć, że gatunki notatek jako schematy mentalne służą nie tylko wspomaganiu pamięci, jak określono w przytoczonych definicjach, ale także ułatwiają tworzenie znaczeń i odnajdywanie sensu w typizowanym i powtarzalnym dialogu, prowadzonym pozornie z samym sobą. Gatunek ten umożliwia bowiem poprawną realizację działań społecznych, zarówno w kontekście zawodowym, jaki prywatnym. Notatki oddziałują bowiem na inne gatunki, stosowane w poprzednich lub przyszłych działaniach. 


\section{Analiza gatunkowa notatek studentów}

W badaniu przeprowadzonym na przełomie maja i czerwca 2018 r. uczestniczyło ośmioro studentów studiów stacjonarnych Uniwersytetu Jagiellońskiego w Krakowie, będących na etapie pisania pracy dyplomowej. Trzy badane osoby to studenci studiów licencjackich, natomiast pozostali to studenci studiów drugiego stopnia. Grupę badawczą stanowią osoby, które zadeklarowały, iż tworzą notatki typu information scraps, co było głównym kryterium doboru próby. Kryterium kompletowania grupy badawczej był również kierunek studiów. Są to reprezentanci różnych specjalności, przy czym połowa z nich, z zamierzenia, jest studentami kierunku Zarządzanie informacją. W celu właściwej organizacji i prezentacji wyników badań ich uczestnicy zostali oznaczeni kodami, wykazanymi w tabeli 1, gdzie R oznacza respondenta.

Tab. 1. Struktura grupy badawczej

\begin{tabular}{|c|l|l|}
\hline Oznaczenie respondenta & \multicolumn{1}{|c|}{ Kierunek studiów } & \multicolumn{1}{|c|}{ Stopień studiów } \\
\hline R1 & Biologia & I stopień \\
\hline R2 & Etnologia i antropologia kulturowa & I stopień \\
\hline R3 & Rachunkowość i zarządzanie finansami & II stopień \\
\hline R4 & Socjologia & I stopień \\
\hline R5 & Zarządzanie informacją & II stopień \\
\hline R6 & Zarządzanie informacją & II stopień \\
\hline R7 & Zarządzanie informacją & II stopień \\
\hline R8 & Zarządzanie informacją & II stopień \\
\hline
\end{tabular}

Wzorując się na podobnych badaniach przeprowadzonych przez Michaela Bernsteina i in., których przedmiotem były information scraps tworzone przez pracowników pięciu organizacji, zdecydowano się na użycie podobnych, wzajemnie komplementarnych, technik i metod badawczych. Są to wywiad oraz analiza gatunkowa zebranego materiału empirycznego w postaci karteczek (Bernstein et. al., 2008, 12). Badania oparte są więc na metodologii jakościowej i podzielone zostały na dwie części, odpowiadające obu wymienionym metodom i technikom.

W pierwszej części badań wykorzystano technikę swobodnego wywiadu ukierunkowanego (zob. Zał. 1). Rozmowy z respondentami trwały od 5 do 15 minut. Zebranym materiałem na tym etapie są spisane wypowiedzi studentów na temat tworzonych przez nich notatek typu information scraps. Respondenci byli pytani o częstotliwość ich tworzenia, najczęściej stosowane formy, cel tworzenia, nie tylko w kontekście studiowania, ale również podczas działań komunikacyjnych wynikających z życia codziennego. Jedno z pytań miało na celu zweryfikowanie, czy podział na sferę prywatną i „zawodową” przekłada się także na proces tworzenia information scraps. Zwrócono również uwagę na potrzeby informacyjne, które towarzyszyły respondentom podczas tworzenia notatek. Ponieważ wywiad poprzedzał zebranie danych empirycznych w postaci notatek, karteczek i skrawków, jedno z zadanych pytań dotyczyło zawartości przekazywanych materiałów, co było istotne dla dalszej analizy materiału empirycznego. Uzyskano także słowną zgodę na wykorzystanie 
przykładów information scraps, pod warunkiem usunięcia danych osobowych lub innych danych mogących wskazywać na konkretne osoby.

W trakcie rozmów wyłoniono wiele przykładów wdrażania indywidualnie opracowanych i stosowanych zasad gatunkowych. Wywiad posłużył również wyłonieniu stanów afektywnych, emocji, odczuć towarzyszących badanym podczas notowania. W czasie prowadzenia rozmów notowano wszystkie wnioski i spostrzeżenia, dotyczące zarówno zauważonych prawidłowości, jak i nowo pojawiających się okoliczności. Następnym krokiem była całościowa analiza wywiadów, których treści podzielono na segmenty dotyczące celu stosowania information scraps w studiowaniu i życiu codziennym oraz zachowań w zakresie zarządzania information scraps przejawianych przez studentów.

Drugą część badań stanowiła jakościowa analiza danych, oparta przede wszystkim na technice analizy treści/zawartości danych zastanych w postaci karteczek i innych notatek zebranych od respondentów, w kierunku ich analizy gatunkowej. Uzyskany materiał to notatki wyłącznie w formie tradycyjnej, papierowej, których treści zapisywane były odręcznie. Część materiału została zarejestrowana na zdjęciach, co pozwoliło na pozostawienie oryginału właścicielowi. W sumie wykonano 42 zdjęcia, z których następnie wyodrębniono pojedyncze information scraps w liczbie 126 notatek. Natomiast karteczki w formie fizycznej występowały w 63 egzemplarzach, co łącznie daje materiał 189 oddzielnych notatek. Materiał empiryczny analizowany był kilkakrotnie i wieloaspektowo, co jest typowe dla analizy danych jakościowych. Podczas analizy danych jakościowych (ang. qualitative data analysis, $Q D A$ ), łączenie gromadzenia danych z ich jednoczesną analizą jest sytuacją typową. Zgromadzony materiał przeanalizowano w kontekście rodzajów zawartych w nim treści w celu wyróżnienia grup tematycznych, oznaczonych następnie literami alfabetu. Zadbano przy tym o uporządkowanie karteczek i oznaczenie ich autorstwa. Podczas tematycznej analizy treści powracano do wypowiedzi respondentów w wywiadach, które precyzowały zawartość notatek. Analizę materiału empirycznego przeprowadzono następnie w odniesieniu do formy notatek: form językowych, jakimi posłużono się do zapisania informacji na information scraps oraz formy materialnej, kształtu i postaci fizycznej karteczek. Analiza gatunkowa zebranego materiału pozwoliła m.in. na wyróżnienie podgatunków notatek.

\subsection{Cel komunikacyjny (wywiady standaryzowane)}

Notatki powstają w związku z pojawianiem się nowych potrzeb komunikacyjnych związanych z określonymi celami. Częstotliwość ich tworzenia jest sprawą indywidualną. Badani najczęściej określali ją wyrażeniami: „często”, „bardzo często”, „regularnie”. Tylko jeden z respondentów (R3) stwierdził, że powstają one „nie aż tak często, na pewno nie codziennie", za to inny (R4) przyznał, że zdarza mu się stworzyć nawet kilka w ciągu jednego dnia. Wzrost częstotliwości następuje przede wszystkim w okresie sesji egzaminacyjnej lub w czasie zdobywania zaliczeń czy podczas przygotowań do społecznych działań związanych z obowiązkami na uczelni. Wywiady wykazały, że powstają one również w momentach przypływu inspiracji, nagłego pojawienia się myśli lub wniosków uznanych za cenne. Także codzienne sytuacje, z którymi związane jest planowanie działań społecznych, stanowi cel tworzenia notatek. Są to najczęściej czynności określane przez studentów jako sprawy bieżące, takie jak zrobienie zakupów czy spotkania w określonym miejscu i czasie. To pozwala na stwierdzenie, iż information scraps powstają w sposób powtarzalny, zwykle ich tworzenie 
jest nieplanowane, ale staje się początkiem planowania innych, wspólnych działań. Te, jako zawierające działania komunikacyjne, powodują stosowanie kolejnych gatunków informacji, służących osiąganiu wspólnych celów. W tym przejawia się oddziaływanie tych gatunków.

Information scraps sprawdzają się podczas wykonywania czynności związanych ze studiami. Czworo respondentów (R1, R2, R3, R6) jednoznacznie stwierdziło, że to właśnie w tym celu powstaje ich najwięcej. Cele związane z sytuacjami codziennymi rzadziej bywają wspomagane przez notatki. Z kolei dla dwóch innych osób (R4, R8) sytuacja jest odwrotna. Tworzone przez nich notatki przeważnie dotyczą działań życia codziennego. Respondent R4 z zaskoczeniem uświadomił sobie, że pomimo zaawansowania jego pracy dyplomowej, notatki jej dotyczące pojawiały się sporadycznie. Przeważnie sięgał po nie w celu zanotowania tytułu lub sygnatury publikacji do wypożyczenia z biblioteki. Zapytany o powód tego zaniechania, stwierdził: „przeważnie do tego aspektu życia wykorzystuję komputer i to tam odbywa się wszystko, co związane ze studiami”. Natomiast pozostali badani (R5, R7) nie potrafili wyraźnie określić, która sfera jest dominująca, gdyż obie grupy celów skłaniają do generowania podobnej liczby notatek.

Respondenci zgodnie uznali, że notatki typu information scraps są dla nich przydatne w dużym stopniu. Dwoje z nich (R4, R8) wręcz stwierdziło, że nie wyobraża sobie funkcjonowania bez nich. Przyczyną była rola notatek we wspomaganiu osiągania celów komunikacyjnych. Najczęściej wymienianą zaletą information scraps było zabezpieczenie przed zapomnieniem informacji. W drugiej kolejności wspominano o porządkowaniu wiedzy/informacji, które ma zapobiec poczuciu chaosu i braku organizacji podejmowanych działań. Respondent R6 oświadczył, że information scraps są dla niego ochroną przed „bezmyślnością pracy”, co może oznaczać wspomaganie procesów poznawczych, w tym komunikacyjnych. Możliwość wyboru i werbalizacji właściwego sposobu postępowania uspokaja respondentów, a także w znacznym stopniu wpływa na systematyczność i konsekwentność ich postępowania. Kilkukrotnie uznawana była także za czynnik motywujący. W takim wypadku information scraps traktowane są jako pierwszy krok do wykonania zaplanowanej czynności, przez co ułatwia mobilizację do kolejnych działań i stosowania kolejnych gatunków. W wypowiedziach badanych często wskazywano na oszczędność czasu rozumianą jako ograniczenie konieczności wielokrotnego wykonywania tych samych czynności. Z jednej strony, respondent R3, który wykorzystywał information scraps do oznaczania ważnych treści w literaturze ${ }^{8}$ związanej z pracą dyplomową, łączył oszczędność czasu z ograniczeniem wysiłku związanego z powtórnym wertowaniem wykorzystywanej publikacji w celu znalezienia interesującego fragmentu. Dzięki wstępnej selekcji istotnych fragmentów tekstu zmniejsza się zapotrzebowanie na pamięć roboczą, dodatkowe informacje kodowane są np. przy użyciu kolorów. Z kolei R6, mówiąc o oszczędności czasu, miał na myśli zminimalizowanie czasu poświęconego na przypomnienie sobie zaplanowanych czynności. Lista zadań pozwala objąć wzrokiem całość zaplanowanych działań, co przyczynia się do wzrostu poczucia posiadania kontroli i panowania nad sytuacją oraz własnymi poczynaniami. Badanie wykazało, że information scraps występują również w roli brudnopisu, z którego treści następnie przenoszone są np. do aplikacji komputerowych lub bardziej sformalizowanych (strukturyzowanych) gatunków. Postrzegane są w charakterze łącznika z innymi gatunkami oraz osobami i ich działaniami.

8 Takie wykorzystanie notatek należy traktować jako narzędzie komunikacyjne (gatunek), ułatwiające znalezienie wspólnego gruntu i uzgodnienie znaczeń pomiędzy autorem tekstu i jego czytelnikiem. 
Analiza postępowania części respondentów pozwoliła zidentyfikować kilka celów information scraps - estetyczny, edukacyjny oraz afektywny. Pierwszy związany był z formą karteczek, przede wszystkim kolorowych i umieszczanych w widocznych miejscach. Respondent R8 stwierdził, iż takie notatki są „przyjemne dla oka” i „ładnie to wygląda jak jest mała karteczka przyklejona" [pisownia oryg.]. Cel edukacyjny przejawia się wykorzystywaniem notatek bądź czynności notowania do nabywania nowych umiejętności. Student R2 przyznał, iż robiąc notatkę typu to-dos ze studencką listą zadań, wykorzystuje ją do ćwiczenia różnych stylów pisma odręcznego, połączonego z praktyką posługiwania się piórem. Respondent stara się wykonywać ją starannie, co ułatwia odbiór treści. Natomiast cel afektywny realizowany jest przez notatki, których treść ma szczególny, sentymentalny charakter dla ich autora. Zrobienie notatki pozytywnie oddziałuje na stan emocjonalny i samozadowolenie jednostki. Zwykle zachowywane są na dłuższy czas. Badany R5 ma tendencję do tworzenia takich treści, przeważnie zawierających cytaty lub myśli zapisywane po to, by „odkryć je za kilka lat”. Przechowuje on je w miejscach widocznych, aby mogły inspirować i motywować do działania lub gromadzi je w specjalnie przeznaczonym do tego zeszycie. Działania takie uznać należy za rodzaj dialogu z autorami cytatów, podczas którego czytelnik tworzy własny tekst (Smagorinsky, 2001, 134).

Wypowiedzi respondentów na temat celów tworzenia information scraps świadczą o ich powstawaniu w typizowanym procesie komunikacyjnym. Wykorzystując information scraps w różnych działaniach i kontekstach porozumiewają się, najczęściej z samym sobą, tworząc notatki na własny użytek. Taki sposób komunikowania można uznać za posługiwanie się własną wiedzą dla jej eksternalizacji w celu modyfikacji lub strukturyzacji (po internalizacji). W tym przypadku intencjonalnym odbiorcą informacji jest jej nadawca, a więc granica między nadawcą a odbiorcą zaciera się. Z drugiej strony, wiele notatek uznać należy za rodzaj dialogu z autorami innych tekstów, innych gatunków. Wynika to z faktu, że notatka, tak jak każdy tekst, uzyskuje znaczenie od sieci innych tekstów, chociażby przez fakt wspólnej przynależności do określonego gatunku lub systemu gatunków. Oznacza to, że notatki są częścią systemu gatunków wspomagającego działania społeczne poprzez wielorakie oddziaływania, towarzyszące procesom komunikacyjnym.

\subsection{Treść notatek (jakościowa analiza danych)}

Zebrany materiał badawczy, w liczbie 189 karteczek, został przeanalizowany pod względem treściowym i skategoryzowany w 15 kategoriach - podgatunkach. Ich oznaczenia literowe oraz liczba notatek przydzielonych do kategorii zostały zaprezentowane w tabeli 2. Kategorie zostały uporządkowane według częstotliwość występowania, od najczęściej do najrzadziej pojawiających się.

Zestawienie to wskazuje trzy najczęściej pojawiające się rodzaje treści information scraps, których liczebność znacznie przewyższa pozostałe kategorie. Są to myśli/opinie/wnioski/spostrzeżenia autora notatki, materiały dydaktyczne/definicje oraz to-dos. Pierwszą z nich i najliczniejszą (36) tworzą swobodne obserwacje, myśli i konkluzje, które są wytworem autora notatki. Są to treści wspomagające naukę, analizy pewnego zagadnienia, zanotowane ciekawostki lub inne informacje przydatne w kontekście pisanej pracy dyplomowej. Notatki te są więc elementem pracy nad wypowiedzią innego gatunku - pracy dyplomowej oraz dialogu z jej przyszłym czytelnikiem. W większości przypadków treść takich information scraps była stosunkowo długa, 
przyjmująca formę jednego, pełnego zdania. Drugą, równie liczną, kategorię (36) stanowią informacje, których zapisanie służy ich utrwaleniu w pamięci. Do tej grupy zaliczane są także definicje terminów, które, jak wynika z przeprowadzonych wywiadów, wspomagają proces nauki. Treść takich notatek najczęściej jest typowa dla klasycznej definicji, składa się z definiowanego terminu (definiendum) oraz wyrażenia definiującego (definiens). Należy je traktować jako efekt czytania, a więc konwersacji z ich autorem. Przykłady notatek obu kategorii przedstawione zostały na rysunku 1 (w prawym górnym rogu znajduje się kod literowy kategorii).

Tab. 2. Kategorie treściowe badanych information scraps wraz z ich liczebnością

\begin{tabular}{|c|l|c|}
\hline Oznaczenie literowe & \multicolumn{1}{|c|}{ Nazwa kategorii } & Liczba notatek \\
\hline A & Materiały dydaktyczne/definicje & 36 \\
\hline B & Myśli/opinie/wnioski/spostrzeżenia autora notatki & 36 \\
\hline C & To-dos & 28 \\
\hline D & Cytaty/„złote myśli” & 16 \\
\hline E & Etykiety/oznaczenia większej partii treści/informacji & 12 \\
\hline F & Metadane publikacji & 12 \\
\hline G & Wątpliwe kwestie do rozwiązania & 12 \\
\hline H & Listy zakupów & 10 \\
\hline I & Nazwy osobowe (imiona i nazwiska) & 7 \\
\hline J & Oznaczenia liczbowe & 7 \\
\hline K & Mieszane & 4 \\
\hline L & Pojedyncze hasła & 2 \\
\hline M & Specjalistyczne/dziedzinowe oznaczenia & 2 \\
\hline N & Zaplanowane spotkania & 1 \\
\hline O & Wykresy/rysunki & 189 \\
\hline
\end{tabular}

Trzecią grupę, obejmującą 28 notatek, stanowią information scraps w formie list to-dos (Rys. 2). Zwykle występowały one w postaci wypunktowanych wykazów czynności do wykonania, lecz pojawiały się również notatki bez wyliczeń, które zaliczane były do tej grupy ze względu na ich treść, wskazującą na przynależność do tej kategorii. Czasami były to szybkie, jednowyrazowe notatki zawierające skróty, których stworzenie nie wymaga dużego wysiłku. Listom to-dos towarzyszyły także specjalne oznaczenia literowe, graficzne, cyfrowe lub znaki interpunkcyjne (np. wykrzykniki), niekiedy kolorowe lub pogrubione dla zaakcentowania wagi czynności. Kilkakrotnie pojawiały się wykreślenia albo zakreślania wyrażające wykonanie lub zakończenie jakiegoś działania. Działania te często wiążą się ze stosowaniem innych gatunków informacji, co wskazuje na oddziaływanie na nie gatunku lista to-dos. Na przykład działanie Zadzwonić w sprawie ankiet (Rys. 2) spowoduje przeprowadzenie rozmowy telefonicznej w gatunku odpowiednim do jej kontekstu.

Należy zwrócić również uwagę na notatki występujące w kategorii D, czyli zapisane cytaty lub „złote myśli” (16 notatek). Treści tego rodzaju chętnie umieszczane są w information scraps. Do tej kategorii przyporządkowywano tylko treści, z których jednoznacznie wynikało, że są to cytaty innych osób niż autor notatki. One także są formą dyskusji z ich autorami. Kierowano się cechami formalnymi (cudzysłowy) lub wskazaniem autora wypowiedzi. 


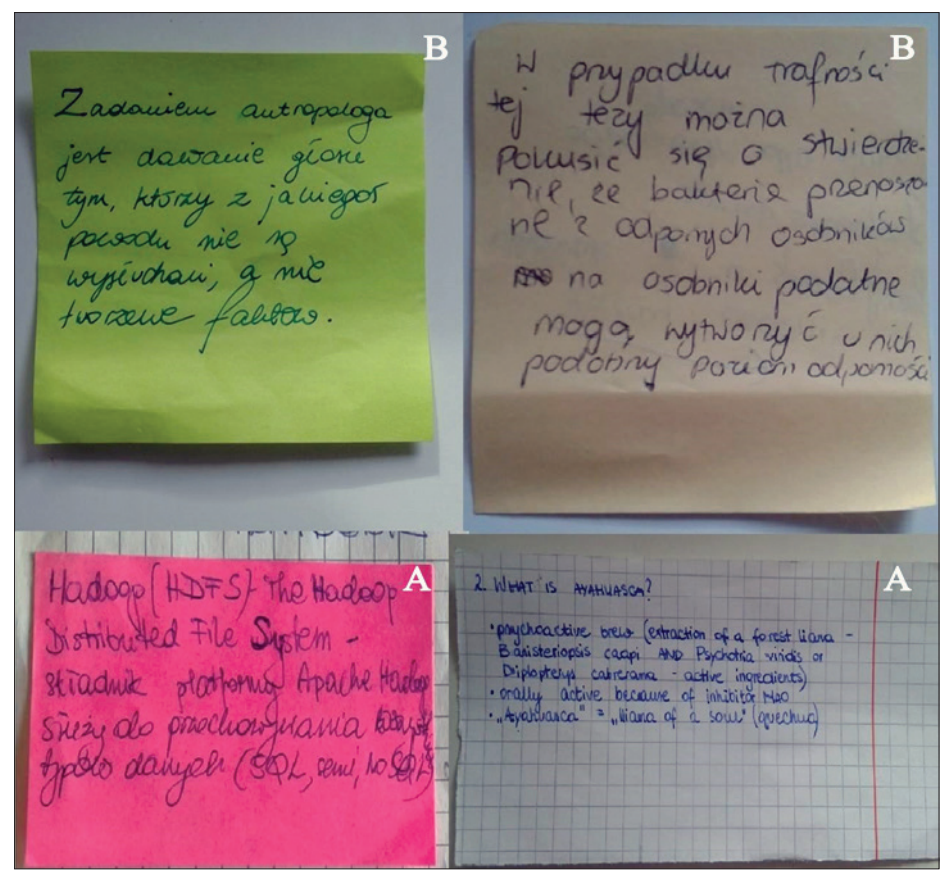

Rys. 1. Przykłady information scraps z kategorii A oraz B

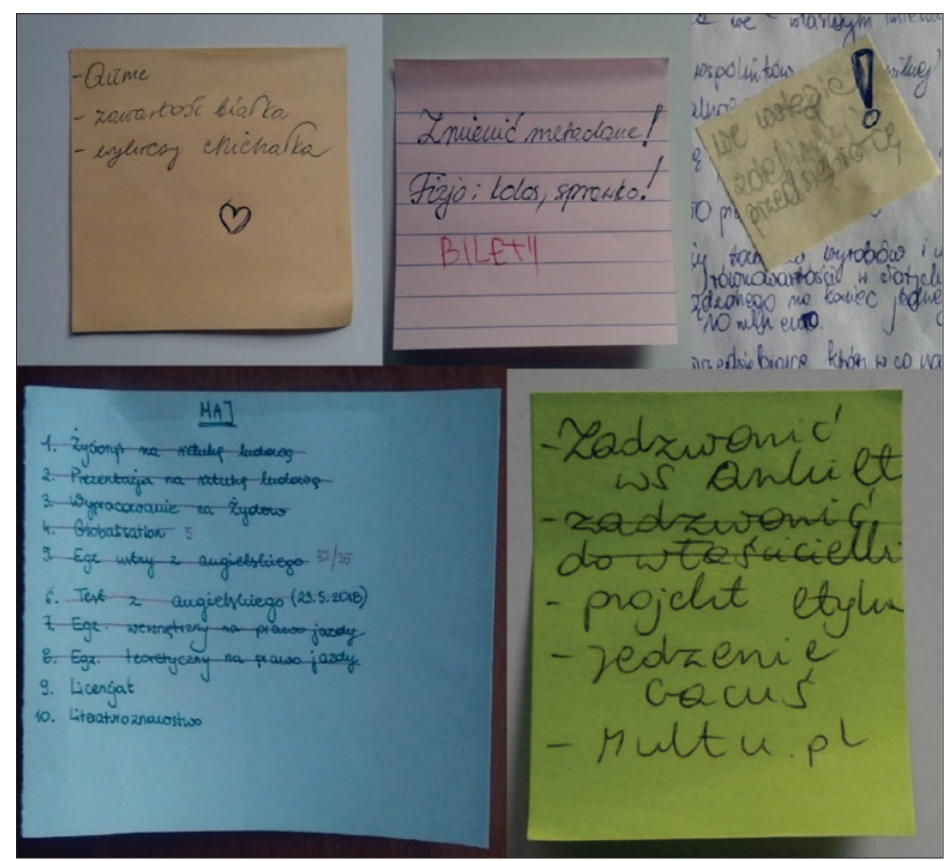

Rys. 2. Sposoby wykorzystywania list to-dos (kategoria C) 
Taką samą liczbę (12) notatek zidentyfikowano w aż trzech kategoriach: E, F oraz G. Wątpliwe kwestie G to grupa notatek, których informacje uzupełniono znakami zapytania, sygnalizującymi wątpliwości autora. Są to nierozstrzygnięte wątpliwości, informacje wymagające sprawdzenia czy dookreślenia. Kategoria F, czyli metadane publikacji to informacje zawierające elementy opisu bibliograficznego: tytuł, tytuł/autor lub rok wydania, wskazujące na planowane działanie uzyskania dostępu do publikacji. Natomiast kategoria E odnosi się do information scraps, które pełnią rolę etykiet bądź oznaczeń większych partii innych treści. Notatki z tej kategorii pojawiały się z reguły na marginesie strony, np. przydatnej publikacji w celu zaznaczenia jej istotnego fragmentu. Należy tutaj zaznaczyć, że kategoria J również obejmuje notatki służące segregacji lub wskazywaniu większej partii informacji, jednak do ich oznaczenia wykorzystano cyfry, stąd takie information scraps przyporządkowano do oddzielnej grupy. Oba te gatunki stanowią formę dialogu z autorem publikacji. W celu zobrazowania różnic pomiędzy tymi dwiema kategoriami, przedstawiono ich przykłady na rysunku 3. Zbliżoną liczbę do trzech powyższych kategorii (10 przypadków) odnotowano dla list zakupów (podgatunek to-dos), oznaczonych literą H. Takie notatki zawierały wyłącznie spisy produktów do nabycia. Te gatunki oddziałują także z gatunkami stosowanymi w kolejnych działaniach, np. etykietami kupowanych produktów. Po 7 przykładów miały kategorie I oraz J. Kategoria I to imiona i nazwiska, najczęściej naukowców (autorów lektur), przez co treści te podobne są do kategorii F. W grupie J znajdowały się wspomniane już oznaczenia liczbowe.

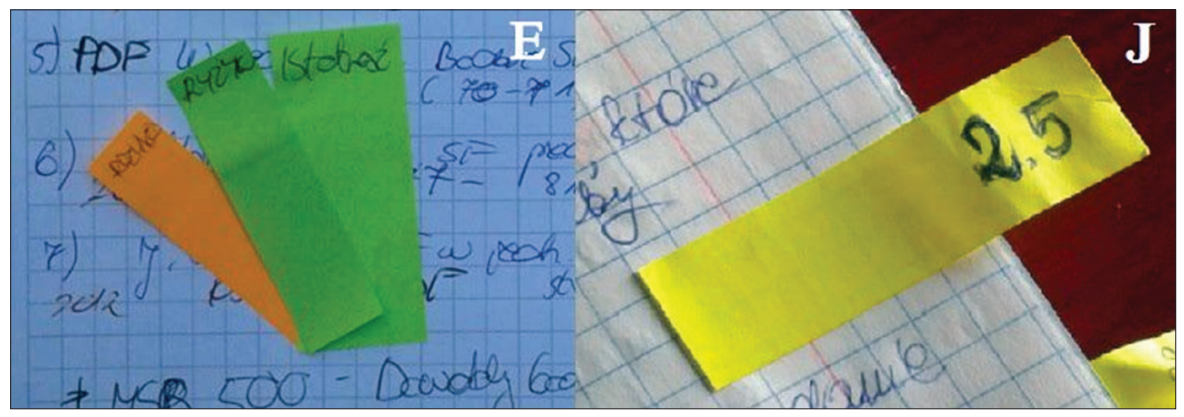

Rys. 3. Różnice pomiędzy kategorią E oraz J

Jedną z ciekawszych information scraps ze względu na treść i formę są notatki kategorii K. Są to notatki, które łączą w sobie treści nawet kilku różnych podgatunków. W zebranym materiale empirycznym znaleźć można przykład połączenia listy zakupów z to-dos oraz kategorią G. Jeden z respondentów połączył kategorie C z G, jeszcze inny B z D. Na jednej z notatek zauważyć można wykorzystanie aż pięciu różnych kategorii: C, G, I, L i M. Wśród zebranych karteczek znalazły się też zawierające nietypowe treści, których dopasowanie do kategorii było niemożliwe ze względu na ich niepowtarzalny charakter. Były to ciągi cyfrowe bądź zestawienia fachowych danych, stąd decyzja o ich umieszczeniu w osobnej kategorii M. Do kategorii N - Zaplanowane zadania przyporządkowano dwie notatki, tyle samo co do kategorii M. Są to krótkie notatki, sprowadzające się do informacji o nadchodzącym spotkaniu, np. miejsce oraz czas. Są one wynikiem dialogu z inną osobą, w którym uzgodniono te informacje. Przykład notatek z tej grupy oraz kilku innych, przedstawiono na rysunku 4. 
Analiza materiału wykazała, że information scraps w formie obiektów graficznych (rysunków) bez tekstów to pojedyncze przypadki. Tylko jedna z karteczek zawierała wyłącznie element graficzny. Był to naszkicowany wykres, który stanowi osobną kategorię O. Rysunki, np. strzałek, znaków wyboru, emotikonów, pojawiały się sporadycznie, tylko jako element uzupełniający treść tekstową.

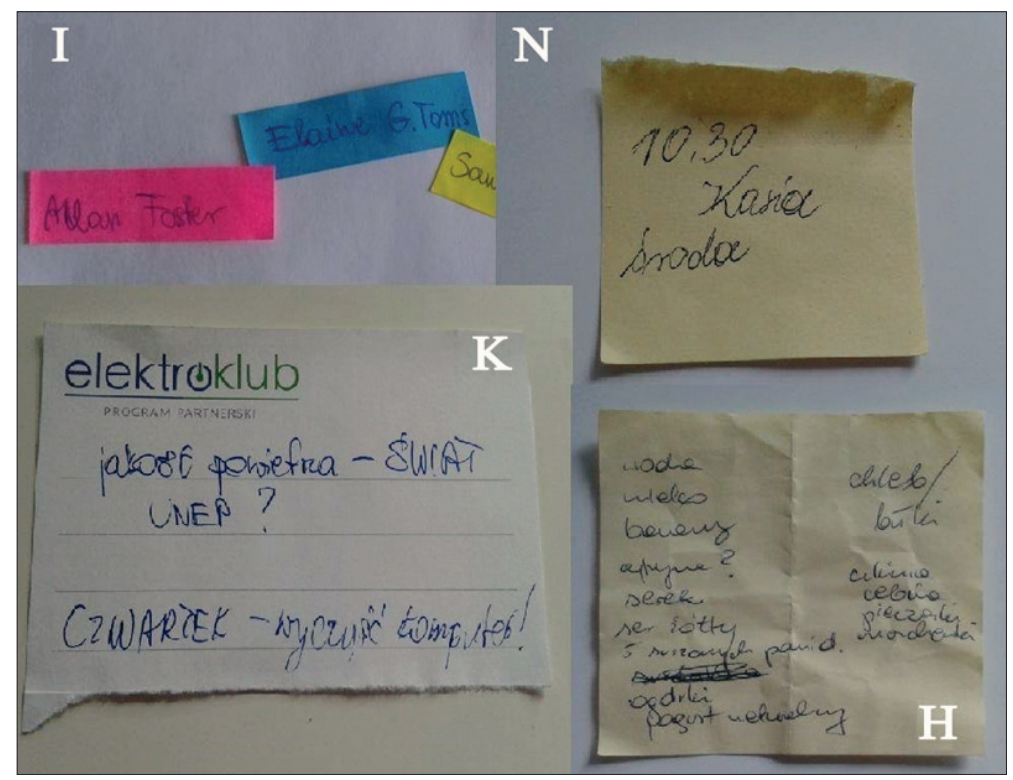

Rys. 4. Przykłady information scraps czterech kategorii: H, I, K, N

\subsection{Forma notatek (jakościowa analiza danych)}

Podczas wywiadów respondenci zwracali uwagę na formę notatek, zarówno fizyczną, jak i językową, jako przyczynę ich popularności. Forma umożliwia mobilność notatek, na co uwagę zwrócili respondenci R2 oraz R4, przyznając, że często towarzyszą im w podróży, np. tramwajem. Są one małe, mieszczą się w kieszeni, co traktowane jest jako istotna zaleta. Student R7 podkreślił, że woli tworzyć właśnie takie notatki, ponieważ sięgnięcie po długopis jest dla niego prostsze, szybsze i wygodniejsze niż wybór i zastosowanie narzędzia elektronicznego.

Analiza notatek pod względem ich formy fizycznej, a więc stosowanych rozmiarów oraz kształtów, wykazała, że najwięcej karteczek (161) miało postać Post-it i stanowiły one $86 \%$ całego zbioru. Ta liczba nie powinna dziwić, ponieważ respondenci, pytani podczas wywiadów o preferowane formy, stwierdzali, iż właśnie z takimi pracuje im się najłatwiej i najwygodniej. Były to karteczki samoprzylepne bądź nie, w różnych kolorach (żółte, różowe, zielone, białe), co miało znaczenie, m.in. podczas lokalizowania notatek w przestrzeni. Miały one różne kształty (kwadratowe, prostokątne) i wielkość. Uczestnicy badania tworzyli information scraps także w innych formach. Zaobserwowano notatki wykonywane na pociętych kartkach zeszytu, oderwanych skrawkach stron, a nawet wyrwanych kartkach z kalendarza (Rys. 5). Pojawiały się także kartki zeszytu A5, przeważnie 
składane w połowie, służące do tworzenia list to-dos, zawierających znaczną liczbę zadań do wykonania. Respondenci wykorzystywali też materiały specjalnie przystosowane do tworzenia notatek. Wiele notatek, szczególnie listy zakupów $(\mathrm{H})$ i kategorii A nosiły ślady intensywnego ich używania i noszenia (zagięcia, pomięcia).
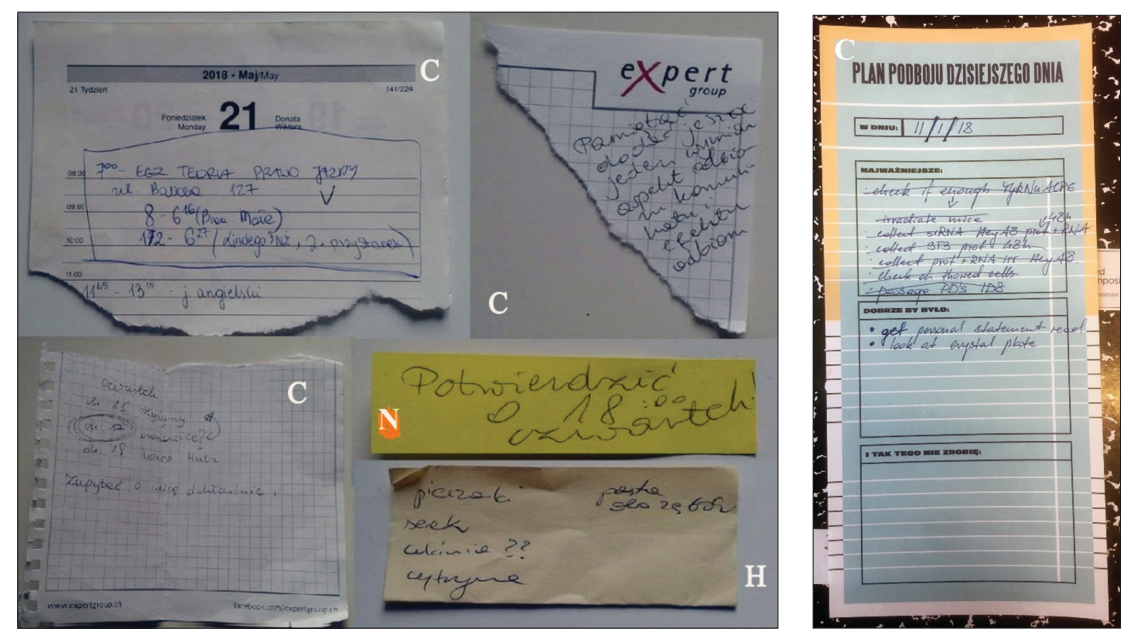

Rys. 5. Przykładowe formy tworzonych information scraps

Analiza materiału badawczego pod kątem form językowych, jakim posługiwali się respondenci wykazała, że zależały one od formy fizycznej information scraps. Wiele z nich składało się z pojedynczych słów, haseł lub wyrażeń, jednak pojawiały się też zawierające dłuższe, dokładniejsze wypowiedzi wyrażane pełnymi zdaniami. Hasłowe treści najczęściej pojawiały się na notatkach typu to-dos i to właśnie w tej kategorii język jest najbardziej zróżnicowany. Występują tu słowa klucze, pojedyncze wyrazy, które szybko skierowują uwagę na odpowiedni rodzaj czynności. W information scraps bardzo często pojawiały się skróty słów, np. sprawko zamiast sprawozdanie czy zad zamiast zadanie. Wypunktowane listy niekiedy pozbawione są czasowników, budowane z samych rzeczowników. Wymienić tu można takie słowa jak: egzamin, esej, jedzenie, wejściówka, projekt, bilety, prezent, mail oraz test. Natomiast na listach czynności znajdowały się takie czasowniki, jak: poszukaj, dopisz, potwierdź, wziąć, zrobić, zmienić, wysłać. Tryb rozkazujący i użyta majuskuła podkreślają wagę treści. Dłuższe i dokładniej formułowane treści zawierały przeważnie notatki z kategorii B i częściowo z kategorii A. Teksty w nich umieszczane były znacznie bardziej rozbudowane, czasem kilkuzdaniowe.

\section{Wnioski}

Zastosowanie teorii gatunków informacji do analizy procesów PIM/GIM przyniosło interesujące efekty. W PIM/GIM stosowane są złożone systemy gatunków informacji wzajemnie na siebie oddziałujących. System taki tworzą również gatunki informacji nazywane w artykule notatkami lub information scraps. Informacje przekazywane za pośrednictwem tych gatunków są przedmiotem społecznych procesów komunikacyjnych, wspierają działania 
kognitywne takie jak organizacja, analiza, wizualizacja informacji oraz uczestniczą w procesach jej internalizacji i eksternalizacji. Działania te prowadzą do tworzenia PSI jednostki w ścisłym związku z PSI innych jednostek. Gatunki, jako element wiedzy, wierzeń, doświadczenia i uprzedzeń, stanowią niezbędną część zarówno indywidualnej, jak również publicznej przestrzeni informacyjnej. Notatki, z zasady tworzone indywidualnie, dotyczą zwykle działań uwarunkowanych społecznie, więc ich miejsce w kontinuum PIM/GIM, choć zwykle bliskie indywidualnego końca, zawsze zawiera element działań grupowych.

Przedstawione badania gatunku information scraps wskazują na nieinstytucjonalne działania zarządzania informacją, które stanowią ważne uzupełnienie działań instytucjonalnych podobnego rodzaju, realizowanych przez biblioteki i inne systemy informacyjne, z wykorzystaniem zupełnie innych gatunków, znacznie bardziej ustrukturyzowanych (standaryzowanych). Badani studenci realizują działania PIM/GIM stale i regularnie, we wszystkich kontekstach, zarówno zawodowym (edukacyjnym), jak i w życiu codziennym, w grupach społecznych różnej liczebności. Wykazują różne schematy zachowań informacyjnych związanych ze stosowaniem notatek, od najprostszych (cel komunikacyjny osiągany najmniejszym kosztem), poprzez średnio złożone (np. zróżnicowanie formy i lokalizacji) po najbardziej złożone, mieszane (stosowanie kilku systemów gatunkowych jednocześnie).

Gatunek information scraps, ułatwiając indywidualne działania kognitywne, jest jednocześnie elementem strukturyzacji działań grupowych i społecznych służących zarządzaniu informacją. Dialog „z samym sobą” jest częścią budowania wspólnego gruntu i przyswajania wspólnych znaczeń. Na tym gruncie dochodzi do porozumienia w działaniu w sytuacjach standardowych i powtarzalnych. Stąd analiza gatunkowa notatek jest tylko jednym z celów przedstawionych badań. Drugim jest prezentacja działań w zakresie organizacji informacji, które tylko pozornie nie służą komunikowaniu tej informacji. W rzeczywistości information scraps, jak i inne podobne gatunki informacji, które przeznaczone są dla ich twórcy (np. pamiętniki), są częścią procesów komunikacyjnych, przeszłych i/lub przyszłych, w których stosowane są gatunki wzajemnie oddziałujące z gatunkiem notatek.

\section{Zał. 1. Zestaw pytań zadawanych podczas wywiadu przeprowadzanego ze studentami}

\begin{tabular}{|c|l|}
\hline Lp. & \multicolumn{1}{|c|}{ Pytanie } \\
\hline $\mathbf{1}$ & Jak często tworzysz tego typu notatki? \\
\hline $\mathbf{2}$ & $\begin{array}{l}\text { Czy tworzysz je wyłącznie podczas pisania pracy dyplomowej oraz innych czynności } \\
\text { związanych ze studiami, czy powstają one również w trakcie czynności życia codziennego? }\end{array}$ \\
\hline $\mathbf{3}$ & Jaką najczęściej przybierają one formę? \\
\hline $\mathbf{4}$ & W jakim celu przeważnie tworzysz takie notatki? \\
\hline $\mathbf{5}$ & Jak bardzo są one dla Ciebie przydatne? \\
\hline $\mathbf{6}$ & $\begin{array}{l}\text { Czy podczas tworzenia notatek, kierujesz się własnym systemem bądź metodą, związa- } \\
\text { ną np. z kolorem, szyframi, szczególnym ich umiejscowieniem? }\end{array}$ \\
\hline $\mathbf{7}$ & Czego dotyczą i co zawierają przekazywane notatki? \\
\hline
\end{tabular}




\section{Bibliografia}

Andersen, J. (2017). Genre, organized knowledge, and communicative action in digital culture. In: J. Andersen \& L. Skouvig (eds.) The organization of knowledge: caught between global structures and local meaning (1-16). Bingley: Emerald Publ. Ltd.

Askehave. I., Swales, J. (2001). Genre identification and communicative purpose: a problem and a possible solution. Applied Linguistics, 22(2), 195-212.

Bachtin, M. (1986). Estetyka twórczości stownej. Warszawa: PIW.

Bernstein, M., van Kleek, M., Karger, D, Schraefel, M. C. (2008). Information scraps: how and why information eludes our personal information management tools. ACM Transactions on Information System, 26(4), art. 24.

Crowston, K., Williams, M. (2000). Reproduced and emergent genres of communication on the World Wide Web. The Information Society, 16(3), 201-215.

Detlor, B. (2010). Information management. International Journal of Information Management, 30, 103-108.

Devitt, A. (2004). Writing genres. Carbondale, IL: Southern Illinois Univ. Press.

Erickson, T. (2006). From PIM to GIM: personal information management in group contexts. Communications of the ACM, 49(1), 74-75.

Franke, W. (1987). Texttypen - Textsorten - Textexemplare. Zeitschrift für germanistiche Linguistik, 15(3), 263-281.

Freadman, A. (2002). Uptake. In: R. Coe, L. Lingard \& T. Teslenko (eds.) The rhetoric and ideology of genre: strategies for stability and change (39-53). Cresskill: Hampton.

Gajda, S. (2009). Gatunki wypowiedzi i genologia. W: Z. Bilut-Homplewicz, W. Czachura, M. Smykała (red.) Lingwistyka tekstu w Polsce i w Niemczech. Pojęcia, problemy, perspektywy (135-146). Wrocław: Oficyna Wydaw. ATUT.

Górny, M., Głowacka, E., Kisilowska, M., Osiński, Z. (2017). Mechanisms of the formation and evolution of personal information spaces in the humanities. Poznań: Wydaw. Rys.

Hyland, K., Salager-Meyer, F. (2008). Scientific writing. Annual Review of Information Science and Technology, 42(1), 297-338.

Isenberg, H. (1978). Probleme der Texttypologie. Wissenschaftliche Zeitschrift der Karl-Marx-Universität Leipzig, 27(5), 565-579.

Jones, W. (2015). Building a better world with our information: the future of personal information management, Part 3. [Chapel Hill]: Morgan \& Claypool Publ.

Jones, W. (2007). Personal Information Management. Annual Review of Information Science and Technology, 41(1), 453-504.

Jones, W., Thorsteinson, C., Thepvongsa, B, Garrett, T. (2016). Making it real: towards practical progress in the management of personal information. In: CHI EA '16 Proceedings of the 2016 CHI Conference Extended Abstracts on Human Factors in Computing Systems (571-582). New York, NY: ACM.

van Kleek, M., Styke, W., Schraefel, M. C., Karger, D. (2011). Finders/Keepers: A Longitudinal Study of People Managing Information Scraps in a Micro-note Tool. In: Proceedings of the 2011 Annual Conference on Human Factors in Computing Systems (CHI'11) (2907-2916). New York, NY: ACM.

Kubiński, W. (2005). Dwa słowa o kognitywizmie i kognitywistyce. W: H. Kardela, Z. Muszyński, M. Rajewski (red.) Kognitywistyka. Problemy i perspektywy (131-136). Lublin: Wydaw. Uniwersytetu Marii Curie-Skłodowskiej.

Kwaśnik, B., Crowston, K. (2005). Introduction to the special issue. Genres of digital documents. Information Technology \& People, 18(2), 76-88.

Lansdale, M. (1988). The psychology of personal information management. Applied Ergonomics, 19(1), 55-56. 
Lin, M., Lutters, W., Kim, T. (2004). Understanding the micronote lifecycle: improving mobile support for informal note taking. In: CHI '04 Proceedings of the SIGCHI Conference on Human Factors in Computing Systems (687-694). New York, NY: ACM.

Ljungberg, J. (2008). Combining Actor Network Theory and genre theory to understand the evolution of digital genres. Sprouts: Working Papers on Information Systems, 8(20).

Luckmann, T. (2009). Observations on the structure and function of communicative genres. Semiotica, 17(1/4), 267-282.

Luckmann, T. (1986). Grundformen der gesellschaftlichen Vermittlung des Wissens: Komunikative Gattungen. Kölner Zeitschrift für Soziologie und Sozialpsychologie, 27, Sonderhefte, 191-211.

Lutters, W., Ackerman, M., Zhou, X. (2007). Group information management. In: W. Jones, J. Teevan (eds.) Personal information management (236-248). Seattle, WA: University of Washington Press.

Maciejewski, M. (2009). Gatunki hipertekstu w perspektywie tekstologicznej. Analiza na przyktadzie internetowych prezentacji przedsiębiorstw. Poznań: WN UAM.

Materska, K. (2012). Wymiary zarządzania informacją indywidualną. W: B. Sosińska-Kalata, E. Chuchro (red.) Społeczeństwo i sieć informacyjna: problemy i technologie (65-79). Warszawa: Wydaw. SBP.

Materska, K. (2010). Rozwój koncepcji zarządzania informacją. W: D. Pietruch-Reizes, W. Babik (red.) Zarzadzanie informacja w nauce (11-22). Katowice: Polskie Towarzystwo Informacji Naukowej.

Miller, C. (1984). Genre as social action. Quarterly Journal of Speech, 70(2), 151-167.

Nahotko, M. (2018). Teoria gatunków w organizacji informacji i wiedzy. Podejście informatologiczne. Kraków: Wydaw. UJ.

Notatka (1979). W: Stownik języka polskiego, T. 2 (395). Warszawa: PWN.

Piolat, A., Olive, T., Kellogg, R. T. (2005). Cognitive effort during note taking. Applied Cognitive Psychology, 19(3), 291-312.

Post-it (2017, August 8). In: English Oxford Living Dictionary [online], [8.08.2017], http://en.oxforddictionaries.com/definition/post-it

Post-it note (2017, August 8). In: Cambridge Dictionary [online], [8.08.2017], http://dictionary. cambridge.org/dictionary/english/post-it-note?q=Post-it+note

Sapa, R. (2017). Grupowe zarządzanie informacją z perspektywy informatologicznej. W: A. Pulikowski (red.) Kultura ksiązki i informacji: księga jubileuszowa dedykowana Profesor Elżbiecie Gondek (267-382). Katowice: Wydaw. UŚ.

Shepherd, M., Watters, C. (1999). The functionality attribute of cybergenres. In: Proc. of the 32nd Hawaii Intern. Conference on System Science (2007-2015), Manui, Hawaii, January 5-8, 1999. Washington: IEEE.

Smagorinsky, P. (2001). If meaning is constructed, what is it made from? Toward a cultural theory of reading. Review of Educational Research, 71(1), 133-169.

Sticky (2017, August 8). English Oxford Living Dictionary [online], [8.08.2017], https://en.oxforddictionaries.com/definition/sticky

Swales, J. (1990). Genre analysis. English in academic and research settings. Cambridge: Cambridge Univ. Press.

Teevan, J., Jones, W., Capra, R. (2008). Personal Information Management. ACM SIGIR Forum, 42(2), 99-105.

Tomaszczyk, J. (2017). Metodyka tworzenia i ewaluacji cyfrowych narzędzi indywidualnego zarządzania informacją. W: R. Sapa (red.) Diagnostyka w zarzadzaniu informacją: perspektywa informatologiczna (209-222). Kraków: Bibl. Jagiellońska.

Wilson, T. (2000). Human information behavior. Informing Science, 3(2), 49-55.

Yates, J., Orlikowski, W. (1992). Genres of organizational communication: a structurational approach to studying communication and media. The Academy of Management Review, 17(2), 299-326.

Yates, J., Orlikowski, W., Rennecker, J. (1997). Collaborative genres for collaboration: Genre systems in digital media. In: Proc. of the 13th Annual Hawaii Intern. Conference on System Sciences (HICCS 30) (50-59), Wailea, HA. Washington, DC: IEEE. 


\title{
Information Scraps Genre in Individual/Group Information Management
}

\begin{abstract}
Purpose/Thesis: The aim of the article is to present the role of information genres in individual (non-institutionalized) information management on the example of a genre system called notes or information scraps created in a traditional way (without the use of electronic tools).

Approach/Methods: The group of students was studied with two complementary methods: an unstructured interview with agenda and the content analysis of collected empirical material (handwritten notes). The interview enabled researchers to collect respondents' opinions on the purposes of using notes. The form and information content of the collected notes was analyzed. This method enabled the information scraps genre analysis, which, according to the literature of the field, should concern three characteristics of the genre: purpose, content and form, including language.

Results and conclusions: Information scraps are a genre system supporting information management. Their form and content are adjusted to the communication purposes: cognitive, affective, aesthetic and educational ones. They are used in the case of standardized and repetitive communication activities. Originality/Value: The use of information scraps in individual activities helps create a common ground for the group activities, hence the genre discussed, just as any other genre, supports social communication activities.
\end{abstract}

\section{Keywords}

Genre analysis. Individual/Group information management. Information genres. Information scraps.

PAULINA KRZANOWSKA, magister zarzadzania informacja na Uniwersytecie Jagiellońskim. Autorka pracy dyplomowej Information scraps jako forma indywidualnego zarzadzania informacja przez studentów. Zawodowo zwiazana z infobrokeringiem. Na co dzień zajmuje się wyszukiwaniem, analiza i selekcja informacji zwiazanych $z$ Kontraktami Armii USA.

Kontakt $z$ autorka:

paulinakrzanowska08@gmail.com

Dr hab. MAREK NAHOTKO, adiunkt w Instytucie Informacji Naukowej i Bibliotekoznawstwa Uniwersytetu Jagiellońskiego, specjalizuje się w zagadnieniach metadanych dokumentów elektronicznych oraz wykorzystania Internetu w komunikacji naukowej i dziatalności informacyjnej. Jest autorem ksiażek Teoria gatunków w organizacji informacji i wiedzy (Kraków, 2018), Komunikacja naukowa w środowisku cyfrowym (Warszawa, 2010), Naukowe czasopisma elektroniczne (Warszawa, 2007), Opis dokumentów elektronicznych. Teoretyczny model i możliwości jego aplikacji (Kraków 2006), Metadane: sposób na uporządkowanie Internetu (Kraków, 2004) oraz licznych artykułów publikowanych m.in. na łamach Przeglądu Bibliotecznego, Zagadnień Informacji Naukowej oraz Bibliotheca Nostra.

Kontakt $z$ autorem:

marek.nahotko@uj.edu.pl

Instytut Informacji Naukowej i Bibliotekoznawstwa Uniwersytetu Jagiellońskiego

ul. prof. Stanisława Lojasiewicza 4

30-348 Kraków 